\title{
MULTIPLE LEVELS IN THE AEGEAN BRONZE AGE WORLD-SYSTEM
}

Paper presented in the Invited Session "Leadership, Production, and Exchange: An Evaluation of World Systems Theory in a Global Context" at the 94th Annual Meeting of the American Anthropological Association, November 15-19, 1995, Washington, D. C.

\author{
P. Nick Kardulias \\ Kenyon College \\ Department of Anthropology and Sociology \\ Gambier, Ohio 43022 \\ kardulia@kenyon.edu
}

Copyright 1996 by P. Nick Kardulias.

\section{v. $7 / 8 / 96$}

\begin{abstract}
Aegean societies in the third and second millennia B.C. developed complex economies based on the accumulation of substantial agricultural surpluses, craft specialization, and intricate distribution systems. The trade items included both utilitarian and luxury goods. To place these activities in a proper context, this paper initially evaluates the world systems literature as it relates to antiquity. The paper then presents some specific evidence to support the contention that the Aegean BA economy was an adjunct to an Eastern Mediterranean world system. While Wallerstein's model offers valuable insights into the operation of trade networks, his approach has certain limitations. The paper explores some of these limitations, in particular the absence of periphery dependence on core areas that is a hallmark of modern capitalist systems, discusses revisions suggested by other scholars, and demonstrates the validity of the altered model with data from the Aegean. The evidence suggests the existence of a system with local, intraregional, and extraregional components. Finally, the paper also suggests that the world systems approach needs to place greater emphasis on production, not just exchange, as the crucial nexus of economic activity.
\end{abstract}




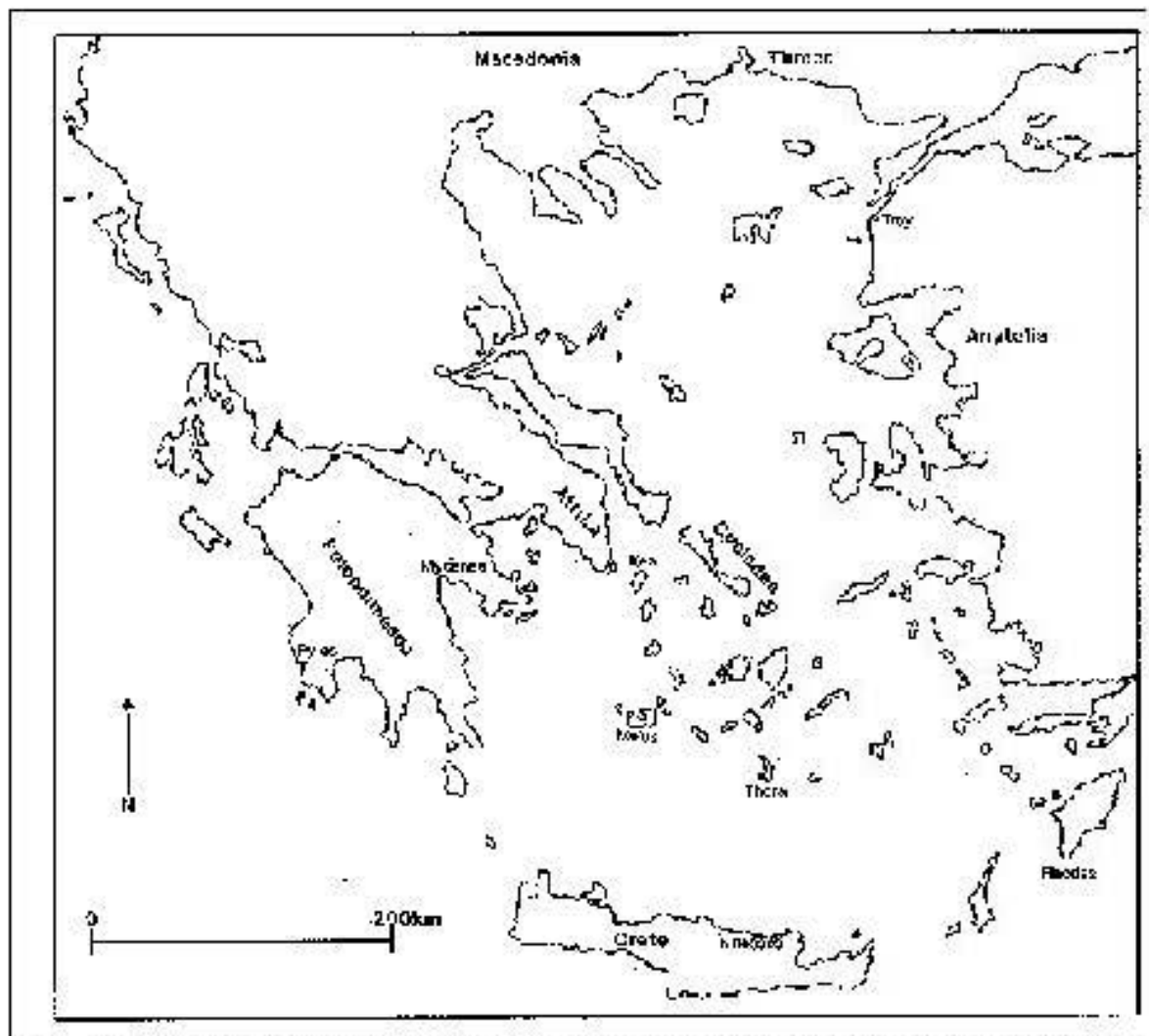

Figre 1. Aap of the Aegean showing some of the lowations mentioned in the text.

\section{[Page 1]}

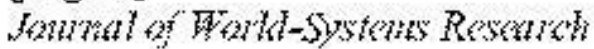

\section{Introduction}

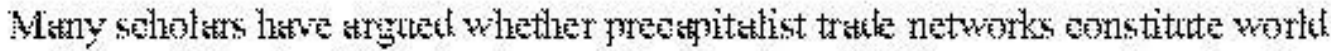

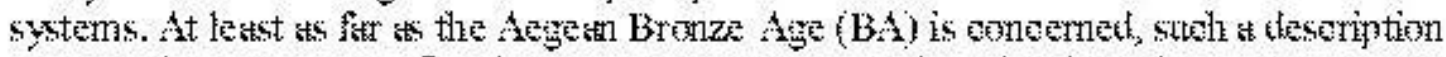

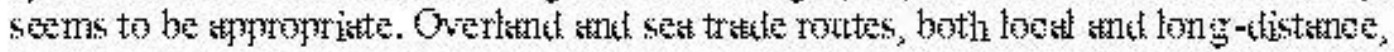

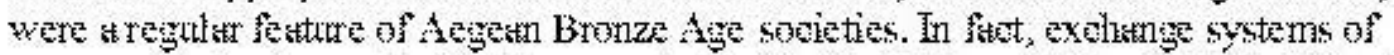

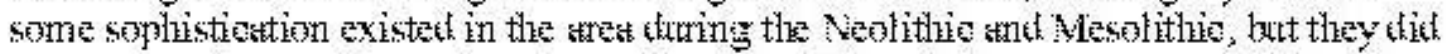
not possess the requisite traits of a world system. The BA, however, was a different story. Aegeatn soejeties in the thirek and seoond millennia B.C. sttained soeial oomplexity (ronkek, stratified, and finally state statts in the Late Bronze Age), vithe well-orgatnizzd

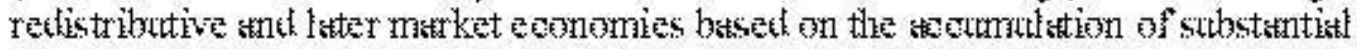
agrienltural surpluses, orth specialization, and thistribution systems vith a watety of

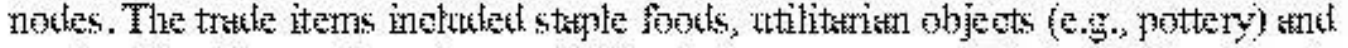
preciosities. But to plate these sotivities in a fropper context, I woukl like to evalukte

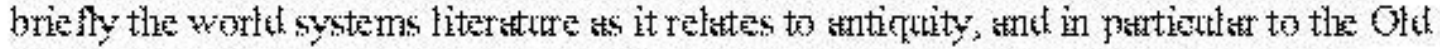
Workt. I will then present some spedifie evikende to support the contention that the Aegean BA economy was an athuthet to an Eastern Mediterratnean world system. While 
Wallerstein's model offers valuable insights to the operation of trade networks, his approach has certain limitations. I will explore briefly some of these limitations, discuss revisions suggested by other scholars, and demonstrate the validity of the al tered model with data from the Aegean. I will also suggest that the world systems approach needs to place greater emphasis on production as the crucial nexus of economic activity.

\section{Economic History-The Ancient Economy}

Before I review the world systems literature, I would like to provide an overview of scholarship on the economic history of the ancient Mediterranean. The ideas of historians have acted as the wellspring for advocates and detractors of world systems theory (WST).

[Page 2]

Journal of World-Systems Research

We can see mirrored in the work of various ancient historians some of the key issues WST confronts. In his monumental work on the Roman and Greek economies, Rostovtzeff discusses the emergence of distinct economic classes. He talks of an urban bourgeoisie that held most of the wealth, while peasant landowners, tenant farmers, day laborers and slaves had minute incomes in the Hellenistic Aegean (Rostovtzeff 1941: 1145, 1149). In order of importance, Rostovtzeff (1941: 1168,1177) lists the key economic activities as agriculture, forestry, mining, and fishing. Agricultural products included wheat, barley, dairy items, honey, olive (fruit and oil), wine, and meat. Systems of production varied according to the need of each area and industry. Rostovtzeff claims that "Decentralization of production became the tendency of the day, and local, not centralized production became the dominating feature of the ceramic industry" (1941: 1210). Metals were high demand objects and generated much commercial activity (Rostovtzeff 1941: 1219). Textiles were important products and exports of Egypt, Phoenicia, Cyprus, and Greek cities of the Anatolian coast, but most households produced material for their own needs (Rostovtzeff 1941: 1222-3,1227). Rostovtzeff suggested trade occurred at two levels. Local trade took place among the parts of the same state or other Greek states, while foreign trade involved regions (e.g., India, Parthia, Illyria) outside that system (Rostovtzeff 1941: 1238). Even in periods of political upheaval, trade in luxury items continued. The foreign goods reached the Mediterranean by core-core exchange; the peripheral zones included such areas as Somalia, Baluchistan, and central Asia (Rostovtzeff 1941: 1245, 1247). Trade in manufactured items was never well developed, perhaps with the exception of luxury goods. Trade networks tapped the vast hinterlands of distant areas. For example, Panticapaeum in the Crimea was an entrepot for fish from the Sea of Azov and items (e.g., animal skins) from the southern Russian steppes (Rostovtzeff 1941: 1263). In a general assessment, Rostovtzeff (1941: 1303) characterizes the Hellenistic economy as capitalism, in which the East eventually incorporated the West in an oikoumene. 
The eminent sociologist Max Weber tackled the problem of how to describe the ancient economy in his book The Agrarian Sociology of Ancient Civilizations. He considered the question whether "Antiquity had characteristics which rule out use of concepts used to analyze the economic history of mediaeval and modern Europe" (Weber 1976: 42). He concluded that, because property was used to make a profit in a market economy, the ancient system qualifies as capitalism. Indeed, capitalism was particularly evident during so-called golden ages (Weber 1976: 51). Public finance, and in particular tax farming, was the major form of ancient capital investment. City states offered greater opportunity for such capital growth because they lacked the restrictive bureaucracies found in monarchies. So for Weber the ancient economy of the Near East and Mediterranean was a variable phenomenon, but

[Page 3]

Journal of World-Systems Research

trade played a major role in a lucrative capitalist system geared to individual profit. $\mathrm{He}$ outlined the major traits of ancient economies: "1) cities exported certain articles of high labor input and quality; 2) cities were constantly dependent on grain imports from distant lands; 3) slaves were purchased; 4) city policies were shaped by specific commercial interests" (Weber 1976: 48). As an extension of this view, Pirenne (1933: 2-5) argued that the well-developed commerce of the ancient world, centered on the Mediterranean, fell apart only after the Muslim conquest of the southern, southeastern, and western shores of the great inland sea. Contrary to Pirenne's view, the Islamic advances did not terminate, but rather reoriented, the system. Europeans had to trade through Muslim commercial centers, such as Damascus and Cairo. In addition, Byzantium offered a series of important emporia, including Constantinople, Smyrna, and Trebizond. One can argue that this system was core-core exchange, but a vast network was tapped.

M.I. Finley developed what some have called the primitivist view of ancient economies. Finley argues that cycles in ancient economies were due to natural catastrophes and political turmoil, and not to supply and demand in a money market. In addition, he notes, in agreement with Rostovtzeff, that manufacturing played a minor role in providing goods to exchange for economic necessities (food, metal, slaves). Furthermore, Finley contends that the much-touted ancient trade network was a restricted phenomenon:

The roll of nearly all the great centers... can be called without going more than a few miles inland. For a long time everything beyond this thin belt was periphery, land to be drawn upon for hides, food, metals and slaves, to be raided for booty, to be garrisoned for defense, but to be inhabited by barbarians, not by Greeks or Romans... To be meaningful, "world market" must embrace something more than the exchange of some goods over long distances... One must show the existence of interlocking behavior and responses over wide areas --Erich Roll's "enormous conglomerate of interdependent markets"--in the dominant sectors of the economy, in food and metal prices, for example, and one cannot (Finley 1973: 34). 
Citing the economic geographer B.J.L. Berry, who noted that central-place settlement hierarchies depend on extensive division of labor and the lack of househ old selfsufficiency, Finley (1973: 34) suggests ancient economies, which lacked these traits, cannot be treated as capitalist systems with well-integrated exchange networks. The economic systems were much more independent. This perspective seems to mirror Polanyi's (1957) approach to ancient

[Page 4]

Journal of World-Systems Research

economic systems as embedded features of the particular cultures. For Polanyi, markets did not characterize ancient economic systems because they lacked the uniformity necessary for such a structure. Some of the readers will recognize in Polanyi's, and by extension Finley's, arguments the basis for the substantivist approach that decries the formalist effort to describe all economic behavior by universal rules of economic behavior.

\section{World Systems Theory}

Wallerstein describes a world-system as one of only two true social systems (the other is the small, isolated society with an autonomous mode of subsistence-e.g., the !Kung San foragers of the Kalahari Desert in southern Africa) because it is self-contained and its developmental dynamics are largely internal. World-systems "...are defined by the fact that their self-containment as an economic-material entity is based on extensive division of labor and that they contain within them a multiplicity of cultures" (Wallerstein 1974: 348). Wallerstein distinguishes between two types of world-systems, world-empires and world-economies; the difference is the presence in the former of a single political structure over a vast area. Capitalism provided stability to the modern world-economy that emerged in the fifteenth century, offered a venue for interaction among a number of nation-states, and provided the means for constant expansion of the European world system. Furthermore, the operation of a world-economy requires the presence of corestates and peripheral areas. Core-states exhibit complex political structures (stratified class systems with large bureaucracies) and, by means of superior technology, control the major facilities of production, transportation, and communication. Political organization in peripheral areas is at the pre-state or incipient state level and is relatively weak compared to that in core-states. Core-states incorporate peripheral areas into the capitalist world-economy because these peripheral regions often contain important natural resources. European core-states controlled the division of labor and reserved those tasks that required a higher level of ability and capital investment for the higher-ranking area, i.e., Europe itself. Through political and economic control of the system, Wallerstein contends, core-states exploited the labor and material resources of peripheral areas and received a disproportionately large share of the surplus or benefits. European nationstates competed among themselves for control or access to peripheral areas in order to increase profits (Wallerstein 1974: 348-350). 
Wallerstein's image of the emergent world-economy and the relationship between corestates and peripheral areas provides an excellent model of European expansion in the early modern period. By presenting incorporation into a world-economy as largely unidirectional, however, Wallerstein oversimplifies a complex process. Hall (1986), among others, argues that one must study the local conditions in peripheral areas as well as capitalist economy in core-states in order to understand fully the nature of incorporation as a variable phenomenon.

[Page 5]

Journal of World-Systems Research

Hall notes that incorporation into a world-economy is a matter of degree and that nonstate peripheral societies play a more active role than generally believed. This aspect is particularly true for various periods in antiquity when complete domination of a peripheral zone was technologically and politically impossible.

A major issue is the degree to which the world systems model applies to the ancient world. Wallerstein suggests the world system was an outgrowth of capitalism and is thus a creation of the sixteenth century. Braudel (1977) be lieves such systems existed in antiquity. An important effort has been Philip Kohl's (1989) revision of world systems theory to fit ancient conditions. In a careful critique of the primitivist views of M. I. Finley and others, Kohl cites many examples of price fixing, inflation, and market mentality that demonstrate the complexity of ancient economies. He builds a strong argument for the existence of an intricate multi-centered world system during the Bronze Age in Southwest Asia. In contrast with modern world economies, ancient technologies were easily transferable from core to periphery, and the latter could offer its resources to competing states and thus retain its autonomy; the lack of major colonization precluded the exploitation and underdevelopment of the periphery. Kohl (1992) explores the coreperiphery relationship specifically as it concerns the Transcaucasus and provides concepts useful for an examination of the Aegean BA. He borrows Chernykh's notion of "metallurgical provinces", defined by "the ir shared utilization of typologically similar metal ornaments, tools, and weapons; by a common technology of metallurgical production; and by the availability of or access to the same metallurgical sources" (Kohl 1992: 134). What he proceeds to say about the Transcaucasus is equally applicable to the Aegean area: If tin was not obtained locally, the very profusion of tin-bronzes in Transcaucasia from Late Bronze times onward suggests an interregional linkage with real economic dependencies (or, better, interdependencies)....The barbarian "peripheries or northern frontiers of Transcaucasia and Central Asia, like their Aegean counterpart far to the west, did not palely reflect the light of civilization emanating from the ancient Near East; rather, they stimulated the latter civilized areas and profoundly affected their courses of development" (Kohl 1992: 134-135). Below, I shall investigate the Aegean BA trade network as just such an interdependent part of a larger world system. While the trade in metals was central to this system, I will examine other commodities that also played a significant role. 
In an effort similar to Kohl's, Zagarell (1989) redefines the relationship between pastoral societies and early states. Similar settlement and subsistence patterns characterized both lowland and highland Mesopotamia until late Middle Chalcolithic times, when the latter reverted to smaller settlements and mobile pastoralism while sites on the alluvial plains increased in size and intensified irrigation agriculture. Zagarell interprets conditions in both

[Page 6]

Journal of World-Systems Research

areas as efforts to enhance production. Due to environmental limitations the highland society could not emulate the lowland model (expansion of agriculture). To enhance production, highlanders turned to pastoral nomadism on a large scale. In an excellent discussion of these complementary developments, Zagarell notes there is no inherent antagonism between pastoral and agricultural societies. This assessment has obvious implications for economic exchanges between such populations and presents a model of core-periphery interaction with no exact modern analog.

In a review of world systems applications, Schortman and Urban (1987: 58 -60) point out some of the problems associated with using the world systems approach in archaeology. First of all, they find limiting Wallerstein's definition of social system primarily in economic terms. Also problematic for them is his neglect of cultural variation as an important component in the interaction process. A significant difficulty is Wallerstein's assertion that precapitalist world systems did not exist; his assertion that precapitalist empires were intrinsically unstable has no empirical backing (Schortman and Urban 1987: 59). A key point is that Wallerstein's stress on the economic aspects of trade obscures the non-economic, non-material elements both of trade and of other types of interaction (Schortman and Urban 1987: 61-62, 1992). In their model of intersocietal contact, Schortman and Urban suggest the units of study should be society and ethnicity, which are connected by the flow of information, i.e., "energy, materials, social institutions, and ideas" and then assume that "Only that information that has the ability to set off positive feedback relations within a society has developmental significance" (Schortman and Urban 1987: 69-69). So, not only trade, but also factors such as shifts in ideologies inspired by the introduction of foreign information can generate social change. Because the various members of the network are affected by the interaction, they use the term coevolution to describe a situation of pronounced intersocietal interaction (Schortman and Urban 1987: 69,76). While I agree that a narrow concentration on trade oversimplifies the process of interaction, I think that a focus on material concerns explains more of the variation in the archaeological record. What, precisely, changes in this process of coevolution? A primary affect is a shift in production, whether it is in terms of intensification of a particular technique, or expansion in an effort to augment the resource base. The use to which the additional products are put will vary according to a range of values, but the realization of the new goals, whether these are strictly material or not, cannot be achieved without augmented surplus. While we cannot read the minds of 
people long dead, we can see the effect on the landscape and in sites of their change in productive capacity. The underlying goal in the ensuing discussion is to demonstrate the role of trade in expanding the productive base of the BA Aegean. Concepts provided by several other authors are useful in this attempt.

[Page 7]

Journal of World-Systems Research

Recently, Chase-Dunn and Hall $(1991,1993)$ have suggested revisions to WST to make it appropriate to a broader historical and geographical context. The basic thrust of their work is "that the fundamental unit of historical development is not the single society, but the entire intersocietal context within which individual societies exist" (Chase-Dunn and Hall 1993). Their goal is to provide a comparative matrix within which to study contacts for all societies, even stateless foraging groups. The interactions, in ascending order of regional extent, involve the exchange of bulk goods, political or military interchange, prestige goods exchange, and information and cultural flows (Hall, personal communication, 1995); more localized interactions can be nested in more extensive systems. Of special relevance to the present study is their definition of two kinds of core/periphery relationships:

The first will be called core/periphery differentiation, in which societies at different levels of complexity and population density are in interaction with each other within the same world-system as defined above. The second type is a core/periphery hierarchy, which will be understood to mean the existence of political, economic or ideological domination between different societies within the same world-system.... We designate two types of core/periphery relations... because we think it is mistaken to assume that all relations among "more developed" and "less developed" societies involve exploitation and the processes of the development of underdevelopment which are of ten found in the modern world-system (Chase-Dumn and Hall 1991: 19).

This distinction places a label on the type of interaction Kohl describes for Southwest Asia in the BA; what he argues for is core/periphery differentiation, and I believe the same term applies to the Aegean BA trade system. Chase-Dunn and Hall then propose a tripartite typology of world systems based on the societal complexity of the most developed societies in each category: 1)Kin-based mode dominant, 2)Tributary modes dominant (urban cultures), 3)Capitalist mode dominant. Category 2 includes both primary empires and multicentered world-systems in which peripheral zones, empires, and autonomous states interact; the Aegean system fits the second of these two classes. From this theoretical edifice, Chase-Dunn and Hall (1991: 27-30) derive four working hypotheses: 1) Social hierarchy institutions are mandatory for intersocietal domination. 2) Stratification in core societies enhances the ability of core/periphery hierarchies to exploit peripheral zones. 3) The development of market exchange, monetary systems, and other mechanisms of trade facilitate the spread to peripheral regions of social and technological 
elements from the core. 4) Social innovation occurs readily in semiperipheral zones because they receive input from cores and peripheries and are

[Page 8]

Journal of World-Systems Research

not burdened by excessive core controls. Chase -Dunn and Hall provide a dynamic, useful model by which to understand the variation in world systems and to test basic concepts. The present study is in part an answer to their call for case studies to provide the comparative data base necessary to test their hypotheses.

Sherratt (1993) has used the term "margin" to refer to a zone that does not interact directly with a core, but does provide materials that are critical to the operation of a world system. He points to the role of amber from the Baltic region and various metals from central Europe in the Mediterranean trade system. The urban core of the Near East and the Aegean in the Bronze Age stimulated the exchange of many commodities through multiple links without members from either geographical extreme ever coming into direct contact. Parts of this system existed in the Neolithic and continued down into historic times, but not without alterations. The trade in metals, especially bronze, was particularly significant; the liquidity provided by bronze made possible the integration of "regional exchange cycles". Sherratt implies the Bronze Age is aptly named, not simply because of the artifacts, but because this metal alloy fueled the economic expansion on which many early states depended.

\section{The Aegean World System}

The Aegean culture area is bounded by the Greek mainland on the west, Macedonia and Thrace on the north, Anatolia on the east and Crete on the south (Fig. 1). The continental shores of the area are heavily dissected and offer numerous good anchorages. For millennia, the rough hinterland has forced the people of the region to look to the sea as the major avenue of trade and communication. Human occupation in the region dates back to the Lower Palacolithic (Tartaron and Runnels 1992), but witnesses no great upswing until the Neolithic. With the exception of Crete and some of the Northern Sporades, none of the Aegean islands was settled until well into the Neolithic. The Bronze Age, however, witnessed a substantial increase in site number, size, and complexity (Cherry 1990; Jameson et al. 1994). The conditions for stratified society developed in the third millennium B.C. and blossomed into state-level organization in the next millennium (Renfrew 1972). Scholars have argued for the primacy of various factors in the emergence of these early state polities, represented by the great palaces at Mycenae, Knossos, Pylos, and elsewhere. Halstead (1981; et al. 1986) stresses the role of social storage in a redistributive economy. Renfrew (1972)

[Page 9]

Joumal of World-Systems Research 
has offered a variety of hypotheses. His subsistence/redistribution model argues that domestication of the vine and olive stimulated the cultivation of marginal lands in the Early BA and led to an increase in population and subsequent stratification through unequal distribution of the wealth generated by the agricultural system. In the craft specialization/wealth model, Renfrew contends that specialized production and trade produced wealth, and stimulated hierarchical social divisions. Van Andel and Runnels (1988) suggest that elites sponsored agricultural enterprises because domesticated products provided much of the trade material by which elites gained their exalted status. These and other views assign trade a critical importance in establishing and maintaining complexity. While trade is only one facet of the total center-periphery connection (Edens 1992: 134), it has received a great deal of attention. Below I will examine the Aegean exchange network as a general system and then how it relates to several specific materials, i.e., obsidian and metal (copper and bronze).

I would like to suggest emendation of the system described by Chase-Dunn and Hall (1991). In particular their conception of the core/periphery differentiation is applicable, with some modifications, to the situation in the BA Aegean. Whereas they see societies at different levels of socio-political integration interacting in such a system, I suggest there are instances in which the groups involved are at the same level of complexity, i.e. peer polities (see Renfrew and Cherry 1986). Furthermore, the specific system in the Aegean had three interconnected, but also separable levels:

1) Internal. Such networks operated within a narrowly defined region in which land transport or short coastal hops sufficed for the transfer of goods. The local systems on Crete, Cyprus, and the Argolid peninsula would be of this type. In each area there existed a group of relatively small states, described as Early State Modules (ESMs) by Renfrew (1984). Within each polity were a number of settlements which exchanged a variety of commodities. I do not mean to suggest that the exchange was egalitarian. Some individuals and settlements certainly acted as key nodes in the system and siphoned off a significant share of the goods. I would argue, however, that there was a rough parity in the economic structure within each of the polities, and that most of the ESMs were on an equal footing. Involved in such exchanges would be a range of goods either native to each region or easily obtained by each.

2) Intermediate. This system encompassed the entire Aegean area and thus involved sea travel between island and mainland. Scholars have formulated various schemes to model this interaction. Cherry and Davis (1982) proposed a "Western String" exchange system in

[Page 10]

Journal of World-Systems Research 
the western Aegean between Attika and Thera, and others have suggested a Minoan thalassocracy in which Crete governed a vast commercial empire. Knapp (1993) denies the existence of such commercial monopolies. Whether one polity or island was preeminent in this trade or not, the exchanges took place between entities of roughly equal stature. The commodities involved in this network probably included some foods, pottery, and certain prestige goods not available locally.

3) Long-distance. In this category would be connections with societies outside the Aegean area, including the Near East, the Anatolian interior, and Egypt. The available evidence indicates that this extrapelagic exchange centered around a variety of goods, including foodstuffs, utilitarian goods, and preciosities. The system brought Mycenaeans and Minoans into contact with the great empires of North Africa and the Levant, but neither side dominated the other, although there certainly was influence (economic, artistic, etc.). In WST terms, this was core-core interaction. It is perhaps at this level that one can best perceive the large-scale BA system which, according to Frank (1993), pervaded the entire Near East and neighboring areas like the Aegean. Frank also discusses the cyclical expansion and contraction of the BA world system. He suggests that the period 1400-1200 B. C., which coincides with the Late BA in the Aegean and will be the focus of much of the discussion below, was a general phase of expansion (Frank 1993: 389).

The Sherratts (1993) discuss the development of a Mediterranean world system in the first millennium B. C. in a similar fashion. They suggest that, in contrast to the Bronze Age, the Iron Age economy exhibited considerable local variation as the result of people taking advantage of regional opportunities. While I believe the BA economy also had considerable local differentiation, I do agree that the system was highly fluid and that individuals played an active role in shaping the exchange networks.

\section{Internal System}

A number of archaeological finds attest to the existence of a fairly extensive exchange system in the prehistoric Aegean. The distribution of non-local goods began in the Upper Palaeolithic, continued in the Mesolithic, gathered momentum in the Neolithic and culminated in the extensive system of the BA. For the earlier periods, obsidian is a good indicator of the

[Page 11]

Journal of World-Systems Research

extent of the system. Sourcing studies by Renfrew and his colleagues (Cann and Renfrew 1964; Renfrew et al. 1965; Dixon and Renfrew 1973) indicate that obsidian from the island of Melos is widespread throughout the Aegean, beginning in the Upper Palaeolithic. For the Neolithic, obsidian has been found at Argissa Magoula, Sesklo (Theocharis 1981: 37), Rakhmani, Dhimini, Tsangli, and other sites in Thessaly (Wace 
and Thompson 1912: 43, 84, 122). Macedonian Neolithic sites with obsidian include Servia (Ridley and Wardle 1979: 229; Watson 1983: 123), Nea Nikomedia (Dixon et al. 1968: 41), Soufli, and Sitagroi (Runnels 1983: 417). In southern Greece Neolithic sites with obsidian include Tsoungiza/Nemea (Blegen 1975: 272), Baroutospilia (McDonald and Hope Simpson 1969: 158), and Lerna I (Caskey 1968: 313). Island contexts include Kephala on Kea (Caskey 1971: 391), Knossos on Crete (Evans 1964: 162), Saliagos on Antiparos (Renfrew et al. 1965: 238), and Aspripetra Cave on Kos (Leekley and Noyes 1975: 29).

During the BA, the number of sites with obsidian increased, as did the quantities of the material present. On the Greek mainland, such sites include Mycenae (Wace 1949: 112; Mylonas 1966: 102), Tiryns (Shelford et al. 1982), Lerna (Runnels 1985b), Prosymna (Blegen 1937: 342), and many spots located by systematic surveys in Messenia (McDonald and Hope Simpson 1969; McDonald et al. 1975: 120), and the southern Argolid (Kardulias and Runnels 1995). In addition, many of the sites from the Neolithic list continued to yield artifacts in the BA. Among the key island sites are Agia Eirini on Kea (Davis 1977: 110, 112, 114, 116), Debla (Warren and Tzedhakis 1974: 332), Myrtos and Mochlos (Warren 1972: 328) on Crete, Phylakopi on Melos (Renfrew 1982: 223), Akrotiri on Thera (Shelford et al, 1982: 190), Kastri on Kythera (Huxley 1972: 217), and several locations in the Dodekanese (Leekley and Noyes 1975:28,31). This is by no means an exhaustive list, but rather serves to provide some sense of the geographic spread involved. In addition to obsidian, the distribution of millstones made of andesite, the sources of which Runnels (1981) identified in the Aegean, demonstrates the existence of significant trade in the Neolithic and BA Aegean (Runnels 1983, 1985a, 1988).

The key point about obsidian procurement is that visitors to Melos seem to have had direct, unimpeded access to this resource (Renfrew 1982: 223-224; Torrence 1986). It seems that travelers roughed out conical cores which they carried back to home sites for final tool production. The distribution of obsidian suggests that people in the Cyclades, Crete, and the Greek mainland all had the opportunity and knowledge to acquire and process the material (Renfrew 1972: 443). If any regulation of the obsidian trade did occur, it is more likely that such control started at the coastal sites where the rough cores arrived. Sites in closest

[Page 12]

Journal of World-Systems Research

physical proximity to Melos have the majority of the cores; as distance from the source increases, the cores disappear while blades persist in the archaeological record. Van Horn (1980) records the relative abundance of blade cores in the Argolid and the accompanying plethora of blades. This contrasts with the situation at Servia in Macedonia where blades seem to have been imported already made since no cores were retrieved during the excavation (Watson 1983: 122). A similar condition seems to have existed on Crete, with cores and blades at Mochlos, but only blades at Debla and Myrtos 
(Warren and Tzedhakis 1974: 332; Warren 1972: 326-328). What we find is that, apart from one or two gateway communities, the distribution of obsidian is relatively uniform throughout the individual regions. In addition, the pattern appears to be the same between regions and suggests that the ESMs attained a certain internal consistency. For example, Bennet (1990: 199-200) argues that the palaces of Crete were indigenous developments and that, despite strong ties among them, no one center held hegemony over the others.

The Linear B tablets from palace archives, especially those of Pylos and Knossos, provide considerable detail on other facets of the internal economic system. Chadwick (1976) has reconstructed many aspects of Mycenaean life from these documents. The tablets from Pylos indicate that the state was composed of a series of communities (damos) intimately tied to the palace. The king (wanax) headed a social hierarchy in which land was assigned by title. Chief-tenants and sub-tenants administered and worked the farm land and produced substantial amounts of wheat and barley. A significant portion of the crop was transferred to the palace storerooms, from where rations were meted out to slaves and others who labored in the palace workshops. In times of need the palace stores sustained a significant number of the region's inhabitants. Other agricultural products involved in this redistributive system were olives, wine, figs, honey, and livestock (Chadwick 1976: 116-128). The image that emerges from the texts is of a centralized system in which land tenure depended on one's relation to the palace. Whether one looks at Pylos, Knossos, or Mycenae, the systems exhibit a considerable degree of homogeneity. Agricultural products found their way into the central storehouses and lesser quantities then went back out through the various channels. An important question is whether these palace economies constituted market systems. There is no evidence of markets in the Linear B texts, but these deal only with the flow of goods into and out of the palaces. There is reference, however, to private property (Chadwick 1976: 117), and there is a stress on profit, whether from crops or secondary animal products, especially wool. In addition, it is hard to imagine that the residents of the villages and hamlets did not periodically gather to exchange what surplus remained after the palace "taxes" were paid. Chadwick (1976: 158) suggests some markets existed, but he questions the

[Page 13]

Journal of World-Systems Research

existence of a regular merchant class.

\section{Intermediate System}

The interchange of material from island to island in the Aegean best represents this level of the Aegean world system. Through this system, products peculiar to specific parts of the Aegean found their way to all corners of the archipelago. In addition, the more productive areas, such as Crete, found outlets for their surplus. The much-debated question of a Minoan thalassocracy in essence asks whether the Cyclades, Dodekanese, and the Greek mainland were peripheries under the core domination of Crete. Although 
not phrased in WST terms, Evans (1921) provided an early expression of this perspective. He believed that Mycenaean civilization not only received its generative stimulus from Crete, but also that the mainland was under the political, economic, and artistic sway of the Minoans. When Wace (1949) and others demonstrated the independence of Mycenae, the way was opened to a more interactive model of Aegean BA economy. The archaeological record indicates a symmetrical economic relationship among many of the settlements, but there is also evidence that Crete's "pull" created some imbalances. In the second millennium B.C., Cycladic culture was a rich fabric of large settlements, unique expressive art, and material prosperity. Much of that prosperity probably derived from the fact that the various islands served as way stations for the commerce between Crete, the Greek mainland, and areas to the east. The "Western String" exchange system proposed by Cherry and Davis (1982) tied Kea, Melos, and Thera into a trading relationship with Attika and Crete. From Laurion in southeastern Attika came lead, used for rivets, plugs, and waterproof linings for storage bins, and silver, an important medium of exchange in the entire region (Weiner 1991a). In the other direction went Minoan pottery, various manufactured status goods, and probably woolen textiles (Finley 1981: 37-38). As the system of trade became increasingly important to Crete, evidence for Minoan infiltration of the Aegean increases. There is a Minoanization of pottery, town-planning, and artistic expression in various important sites, such as Akrotiri on Thera and Trianda on Rhodes. From such evidence, Weiner $(1984,1991 \mathrm{a}: 31)$ argues for the presence of many Minoans or their descendants in the Cyclades and Dodekanese, but the nature of the contacts "may include casual, unofficial, small-scale migration involving merchants...or an expanding Minoan elite seeking to carve out baronies, or a Cretan nobility exercising loose diplomatic control". The Aegean intermediate or regional world system benefitted many local communities and engendered, at most, a loose confederation within which Crete was unable to exercise hegemony even though her dynamic economy and elites generated much of the

[Page 14]

Journal of World-Systems Research

demand for goods that raised production levels and stimulated trade. While certain individuals may have desired to control the system, they could not fully exploit it because of the number of middlemen, and their relative isolation on so many islands.

\section{Long-Distance System}

The trade in obsidian and certain other commodities seems to have been limited to the immediate circum-Aegean region. Other items, however, traveled much further and brought the Aegean world into contact with Near Eastern civilizations and peripheral zones. A wealth of evidence has appeared from the hold of a Late BA (ca. 1400 B.C.) shipwreck excavated by George Bass and his colleagues (1986; 1989; Pulak 1988). The Ulu Burun wreck, off the southwest tip of Anatolia, was a merchantman returning from an expedition to the Levant and Cyprus. The ship contained both raw and manufactured 
goods. In the former category are copper and tin ingots in the ox-hide shape, spherical glass ingots, unworked elephant and hippopotamus ivory, orpiment (arsenic trisulfide--a pigment), myrrh and frankincense (Bass 1986), and two logs of Egyptian ebony (Pulak et al. 1992). Foodstuffs included pomegranates, acorns, figs, grapes, olives, almonds, safflower, wheat, barley, pulses, coriander, sumac, and probably wine and olive oil (inferred from the great number of amphorae); the cargo also included an estimated one metric ton of terebinth resin, used in the producton of aromatic oils and emollients (Bass 1986; Haldane 1993; Pulak et al. 1992). The finished products included Cypriot pottery, Syro-Palestinian pottery, gold and silver jewelry of Canaanite form, bronze tools and weapons, hematite weights, stone artifacts, beads of faience, glass, and amber (Bass 1986), two Near Eastern (Kassite) cylinder seals, and a gold scarab with an inscription indicating an 18th Dynasty Egyptian origin (Bass et al. 1989). The ship was travelling east to west at the time it met disaster. Pulak (1988: 36-37) suggests the ship had a Mycenaean origin, with landfalls at Syrian ports (e.g., Ugarit), and Cyprus; it may have been headed for Rhodes or the Anatolian coast, with a high probability that much of the copper was destined for Crete, and a subsequent continuation to Egypt is a possibility. An Aegean-Egyptian connection is well established. In Egyptian texts and funerary art, individuals identified as Keftiu, and dressed like Minoans, are depicted delivering goods to Pharaoh and other lords. In addition, a substantial amount of Minoan pottery appears in Egyptian contexts (Kemp and Merrillees 1980). What is clear is that the Ulu Burun ship was not unique and that an extensive network connected the Aegean directly to North Africa, the

[Page 15]

Journal of World-Systems Research

Levant, Cyprus, and the Anatolian coast. Beyond the direct ties, indirect trade linked the Aegean with the Anatolian interior and Mesopotamia.

The metals trade is the best example of the international commerce in which Aegean peoples engaged. Borrowing from Kohl, I would suggest the existence of an Aegean or Eastern Mediterranean metallurgical province that clearly represents a world system, but one with a core-core relationship. Sherratt (1993) has argued that bronze was the critical commodity whose liquidity facilitated the integration of regional exchange systems; elite demand for bronze greatly stimulated metal production. Bronze was a critical resource in the BA Aegean because it provided weapons, tools for the construction of the great palaces, and prestige objects (Weiner 1991a: 22, 1991b: 327). Weiner (1991a: 23) contends that the economic and political security of the Minoan elites depended on bronze, and thus the procurement of the metal "would have been the object of intensive search, planning, and investment". Edens (1992: 126) makes a similar argument for the Mesopotamian world system. He suggests that the shift from chert to copper or bronze sickles and other tools reflects increased economic and probably political centralization because metals are rarer and more difficult to obtain. In addition, he argues that luxuries became necessities in the Persian Gulf trade. Several questions arise from Edens 
argument: Did people have to accede more to the demands of the elite, who controlled the metal trade? Does trade in certain materials, especially metals, become institutionalized? To answer such questions, which place trade in its larger cultural context--Edens (1992: 134) argues trade is just one facet of core-periphery relationships and cannot be comprehended without consideration of warfare, diplomacy, cultural hegemony, and the social contexts of production and consumption, much in the way that Chase-Dunn and Hall (1991) argue for the nested nature of these relationships--one must consider the procurement, production, and consumption systems. I will now turn to a consideration of each of these components of the Aegean economic system.

Procurement required extensive contacts. The Aegean has only a few large sources of copper. Lead isotope analyses (Gale and Stos -Gale 1982) have identified several key sources for BA artifacts; these include Kithnos, Sifnos, Laurion, and Cyprus, with the latter two by far the most important by the Late BA (see Budd et al. 1995 who dispute the interpretation). The other critical component required to make a good bronze alloy is tin, which is much rarer than copper. There is considerable debate about the sources of the tin used in the manufacture of Aegean bronze. Yener and others suggest the deposits near Kltepe in Anatolia were mined in the BA, but Muhly and others disagree. Weiner (1991a: 23) suggests three possible island chains comprised the major routes in the Aegean, especially Minoan,

[Page 16]

Journal of World-Systems Research

search for copper and tin. One was to the north through Thera, Naxos and Kea to Laurion--Cherry and Davis' "Western String". A second went east to Cyprus and on to the Levant, and perhaps on to Mersin in southern Anatolia, with stops at Kasos, Karpathos, Chalki, and Trianda (Rhodes). The third route followed the west coast of Anatolia to Knidos, Iasos, Miletos, Teichiussa, then to Troy by way of Samos; stops on this route could have included Kalymnos, Telos, Nisyros, Astypalaia, and Kos. Obviously, the Aegean merchants merely bartered for ingots at the various ports of call. The Ulu Burun wreck gives us an indication of the quantities involved. The ship was carrying about $300 \mathrm{ox}$-hide copper ingots (average weight: $25 \mathrm{~kg}$ ) and a dozen tin ingots. These quantities surpass those recorded in many ancient Near Eastern texts (Pulak 1988: 34-35). If we assume that this shipment was large, but not unique, we get some idea of the scale of the metal trade.

A second, but equally important, problem in evaluating the trade network is the administration of the system. It is clear that by the Late BA, Crete and the mainland had well developed palace bureaucracies that had a major interest in the metal trade. But did the palaces regulate and subsidize the long-distance trade or did independent merchants undertake the ventures? Branigan (1982) suggests there was free-lance trade in metals. I agree with Weiner $(1987: 264)$ that the role of copper, bronze, and other metals to the elites was of such importance that the expeditions were planned and subsidized by the by 
the palaces. The importance of copper and bronze in particular has already been discussed above. There is clear evidence in the distribution of bronze artifacts for privileged access. Just as significant is the evolution of written scripts by which the palaces administered the metal trade. Some have argued that the administrative system based on seals and writing was borrowed from the Near East as a result of commercial contacts. While there is no doubt about Aegean familiarity with Near Eastern peoples and products, the process of diffusion is complex. It is important to note that when Cyprus becomes a major supplier of copper to Crete, people on the former island opt for Minoan Linear A rather than cuneiform as the administrative script (Palaima 1989; Weiner 1990: 236). As Weiner (1987: 263) has stated: "any amount of trade at a given time can take place without writing, but both complex administration and investment over time require literacy. Providing ships and goods for extensive overseas trade involves an investment over time." Thus, the Aegean world system involved the emergence of social hierarchies, but none of the major trading partners had the ability to dominate the others, i.e., there is no development of a classic core-periphery dependency relationship.

Production involved several different levels. Smelting was often performed at or near the quarries. Alternatively, certain sites intermediate between the inland quarries and the coast provided this service; for example, the site of Pamboulari tis Koukouninas near

[Page 17]

Journal of World-Systems Research

Athienou in central Cyprus is some distance from both the copper-bearing mountains and the sea (Dothan and Ben-Tor 1983). Keswani (1993) argues there were eight copperproducing polities on LBA Cyprus, and these centers provided raw material for the Aegean. The ingots were then transported to coastal areas (mentions of donkey caravans in some texts) and transhipped to the various Aegean locales. The transformation into finished products took place under the watchful eye of the palace administrators. The best evidence for the system comes from the tablets at Pylos. These tablets were meant as only temporary records on unbaked clay; the conflagration that destroyed the palace ca. 1200 B.C. fortuitously fired the documents and made possible their preservation. The tablets thus provide inventories for one season, or at best, one year in the palace system. Scribes recorded the quantities of bronze allotted to bronzesmiths in the palace and in surrounding communities from palace stores. A system of weights and fractions permitted accurate recording of the quantities so assigned. Metal smiths may have emerged as specialists in the Middle BA; there is a smith's shop at Malthi (Messenia) and possibly another at Lerna (Argolid) in the pre-palatial period on the mainland (Vermeule 1964: 75, 228). Each tablet in the Jn series from Pylos provides a place name, list of the smiths and the quantity of bronze allotted to each, and a total; there is commonly another list of smiths who received no metal. It seems that approximately one-third of all the smiths were not working metal at the time tablets were written; the remainder may have been involved in subsistence activities, and suggests the presence of part-time specialists who could be called upon when conditions required a larger professional work force. 
Chadwick (1976: 140-142) estimates there were close to 400 smiths in the Pylos kingdom. Palace control of the metal industry is suggested not only by the disbursements recorded in the tablets, but also by the concentration of smiths in certain areas, with up to 26 in one locale. The amounts of bronze assigned to each smith are relatively small, with a range from 1.5 to $12 \mathrm{~kg}$ and an average of $3-4 \mathrm{~kg}$. Total quantities are significant: one tablet records $1,046 \mathrm{~kg}$ and another $1,562 \mathrm{~kg}$. The artisans fa shioned a wide range of artifacts from bronze: pots, cups, braziers, knives, axes, adzes, tweezers, razors, saws, chisels, awls, scale pans, lamps, and a wide assortment of military equipment, including daggers, swords, spearpoints, arrowheads, armor, helmets, and bindings on chariot wheels (Chadwick 1976: 142-143). Estimates suggest that from a ton of bronze the smiths could manufacture 534,000 arrowheads or 1,000 helmets (Vermeule 1964: 228).

Just as important as productive capacity are the relations of production. As mentioned above, the smiths were under palace direction. They worked, in large part, at the sufferance of the central administration, which hoarded the supply of raw materials. Despite the quantities mentioned in the tablets, bronze was gene rally in short supply and palace officials regulated its flow. Chadwick (1976: 141-142) detects a distinct note of urgency in the Pylos

[Page 18]

Journal of World-Systems Research

system of rationing. Bronze was in relatively short supply and its use was prioritized, with military concerns primary. Tablet Jn 829 details contributions of bronze from local governors requested by the palace in order to make spear and javelin points. One assumes the bronze was gathered and then distributed to the smiths, who melted down the artifacts and produced the weapons, which were, in turn, returned to the palace. Other evidence for the existence of a crisis is found on tablets (An 657, An 654, AN 519, An 656, An 661 ) that mention groups of coast watchers "guarding the coastal regions" under the direction of royal officials; the subsequent destruction of the palace is mute testimony to the inability of the administration to handle the situation (Chadwick 1976: 175-177). The bronzesmiths can be classified as attached specialists whose role as artisans was subsidized, directed, and in large part developed because of the needs of the palace elite. The palaces would have supported other specialists, such as potters, fresco painters, architects, stone masons, and lapidaries, the bulk of whose products ended up in royal storerooms. To be certain, there must have been other artisans, full-time and part-time, who provided various goods and services to non-elites, but economic specialization seems to have been rather centralized.

The metal artifacts were largely consumed by elites. Large quantities of bronze swords, daggers, and armor have been found in Mycenaean and Minoan tombs. These objects probably represent the military nature of the hierarchy that held sway on the Greek mainland and at Knossos in the Late BA. Gilman (1981) has argued that such objects in the European BA bespeak societal domination by a warrior class. Nothing from the 
Acgean contexts seems to dispute that claim. The Shaft Graves in Grave Circle A at Mycenae date to the early Mycenaean (early Late BA, ca. 1550-1450 B.C.) and provide good evidence for the concentration of wealth by the elite. A partial inventory from Shaft Grave IV in Grave Circle A includes three gold masks, two gold crowns, eight gold "diadems", 27 swords, five daggers, 16 knives, five razors, 22 bronze vases, 38 arrowheads, 683 gold discs and repoussé ornaments (Vermeule 1964: 88 -89); there are a host of other objects, but even this incomplete list of the metal offerings demonstrates the exalted status of those interred. In addition to the bronze, other materials of foreign origin were found in this grave: ostrich eggs (Nubia), lapis lazuli (Afghanistan by way of Mesopotamia), alabaster and faience (Crete), ivory (Syria), silver (Anatolia), amber (Baltic region) (Vermeule 1964: 89). Excavations at Aegean BA sites over the past 125 years have revealed a decidedly skewed distribution of such materials. The luxury items appear in abundance in tombs and palace destruction levels at the major centers and in smaller amounts in large residences at secondary sites. In addition to domestic consumption, metal artifacts were probably also key exchange items in trade among the

[Page 19]

Journal of World-Systems Research

Aegean polities and with the more distant members of the world system (e.g., Egypt, Anatolia, Syria). Chadwick (1976: 141) argues, correctly I believe, that the suggested number of 400 smiths in Pylos produced a significant surplus, beyond domestic (elite and non-elite) needs, of bronze objects, many of which were exported by sea. The foreign trade, especially that in metals, was central to the Aegean BA economy and its disruption could have had disastrous consequences for the palace administrative systems. Such a disruption did occur in the 12 th and 13 th centuries B.C. and the entire eastern Mediterranean world system suffered a serious decline. The Aegean branch of that system did not recover. Many scholars cite the invasions of the so-called Sea Peoples, recorded in Egyptian documents, as the series of events in the Late BA that reflect the dislocation of many people in the eastern Mediterranean; the movements of these people in their search for new homelands upset the political and economic system in the region (Knapp 1992). The collapse of the trade system led to the decline of the Aegean elites. Perhaps more important than the exchange system per se was the decline in production, with its stimulative impact on society (Harris 1991: 21-23).

\section{Conclusion}

In sum, the Aegean trade system was extensive and administered by the palaces in the Late BA. It brought into contact a variety of cultures with well developed economies and an appetite for prestige and utilitarian goods. Because of the distances involved and the lack of direct control of sources of raw materials, no dependent core-periphery relationships emerged between the Aegean and the other major players (Egypt, Mesopotamia, Levantine states). This does not minimize the importance of the world systems perspective for providing a theoretical approach to understand the context of 
interaction. Wallerstein's original formulation is flexible enough to accommodate the somewhat different economic conditions of antiquity. What is clear is that there was in place an interaction sphere that involved several different levels. The local system involved the exchange of materials within the ESMs. The Aegean system encompassed an interaction sphere in which the mainland and islands participated. With the exception of possible Minoan colonists on some Aegean islands and the Late BA Mycenaean occupation of Knossos, the Aegean core polities (e.g., Mycenae, Knossos, Pylos) did not maintain a permanent residence in areas from which they derived materials. The extraction of raw materials was locally controlled; contact with the Aegean ESMs stimulated production, but did not evidently lead to political domination. The Eastern Mediterranean world system was an international interchange that involved the transfer of

[Page 20]

Journal of World-Systems Research

both bulk goods and preciosities to and from the Aegean, Egypt, the Syro-Palestinian coast, Cyprus, and Anatolia. Direct Aegean contacts were limited to coastal areas in these other lands. The network, however, did extend far beyond the littoral zones. Tin came from the interior of Anatolia, ostrich eggs and gold from as far as Nubia, aromatic ointments from the Arabian peninsula, cylinder seals from Mesopotamia. There is some evidence to suggest that the procurement of the raw materials in some of these areas was accomplished by way of direct core exploitation of peripheral areas. For example, cuneiform tablets indicate that Assyrian traders established an outpost at Kanesh (Kültepe) in central Anatolia in ca. 1950 B.C., and from this site exported tons of copper to Mesopotamia. The texts also explain that Kanesh was the central node in a series of nine Assyrian outposts in the region (Özgüç 1963). Furthermore, if the name "Kaptara" refers to Crete, as many scholars believe, then the mention in a Mari tablet of a man from this area as the recipient of tin from the east (Weiner 1991b; 328) establishes the link between the Mesopotamian and Aegean world systems. While the relationships among the various participants in the interlocking exchange systems varied, there is a clear reliance by urban centers on products or materials available in marginal zones. The inability, in most cases, of the core states to muster sufficient manpower to subjugate the peripheral areas precluded the development of a dependent role for the latter. With the modifications mentioned above, the term world system still serves well to characterize the internal and external relations of the late prehistoric Aegean area in the BA.

\section{REFERENCES CITED}

Bennet, J.

1990 Knossos in Context: Comparative Perspectives on the Linear B Administration of LM II-III Crete. American Journal of Archaeology 94: 193-211. 
[Page 21]

Journal of World-Systems Research

Bass, G.

1986 Bronze Age Shipwreck at Ulu Burun (Ka): 1984 Campaign. American Journal of Archaeology 90: 269-296.

Bass, G., C. Pulak, D. Collon, and J. Weinstein

1989 The Bronze Age Shipwreck at Ulu Burun: 1986 Campaign. American Journal of Archaeology 93: 1-29.

Blegen, C.

1937 Prosymna. The Helladic Settlement Preceding the Argive Herae um. Cambridge University Press, Cambridge.

1975 Neolithic Remains at Nemea. Hesperia 44: 224-279.

Branigan, $\mathrm{K}$.

1982 Minoan Metallurgy and Cypriot Copper. In Early Metallurgy in Cyprus, 4000-500 B.C., edited by , pp.208-210. Nicosia.

Braudel, F.

1977 Afterthoughts on Material Civilization and Capitalism. Translated by P. M.

Ronaum. John Hopkins University Press, Baltimore.

Brumfiel, E., and T. K. Earle

1987 Specialization, Exchange, and Complex Societies: An Introduction. In Specialization, Exchange, and Complex Societies, edited by E. Brumfiel, and T. K. Earle, pp 1-9. Cambridge University Press, Cambridge.

[Page 22]

Journal of World-Systems Research 
Budd, P., A. M. Pollard, B. Scaife, and R. G. Thomas

1995 Oxhide Ingots, Recycling and the Mediterranean Metals Trade. Journal of Mediterranean Archaeology 8: 1-32.

Cann, J. R., and C. Renfrew

1964 The Characterization of Obsidian and its Application to the Mediterranean Region. Proceedings of the Prehistoric Society 30: 111-133.

Caskey, J. L.

1968 Lerna in the Early Bronze Age. American Journal of Archaeology 72: 313-316.

1971 Investigations in Keos. Part I: Excavations and Explorations, 1966-1970. Hesperia 40: 359-396.

Chadwick, J.

1976 The Mycenaean World. Cambridge University Press, New York.

Chase-Dunn, C., and T. D. Hall

1991 Conceptualizing Core/Periphery Hierarchies for Comparative Study. In

Core/Periphery Relations in Precapitalist Worlds, edited by Christopher Chase-Dunn and Thomas D. Hall, pp. 5-44. Westview Press, Boulder.

[Page 23]

Journal of World-Systems Research

1993 Comparing World-Systems: Concepts and Working Hypotheses. Social Forces 71: 851-886.

Cherry, J.

1990 The First Colonization of the Mediterranean Islands: A Review of Recent Research. Journal of Mediterranean Archaeology 3: 145-221.

Cherry, J., and J. L. Davis

1982 The Cyclades and the Greek Mainland in LCI: The Evidence of the Pottery.

American Journal of Archaeology 86: 333-341.

Davis, J. L. 
1977 Fortifications at Ayia Irini, Keos: Evidence for History and Relative Chronology. Unpublished Ph.D. Dissertation, University of Cincinnati.

Dixon, J. E., J. R. Cann, and C. Renfrew

1968 Obsidian and the Origin of Trade. Scientific American 218(3): 38-46.

Dixon, J. E., and C. Renfrew

1973 The Source of the Franchthi Obsidians. Hesperia 42: 82-85.

[Page 24]

Journal of World-Systems Research

Dothan, T., and A. Ben-Tor

1983 Excavation at Athienou, Cyprus, 1971-1972. Qedem 16. Hebrew University, Jerusalem.

Edens, C.

1992 Dynamics of Trade in the Ancient Mesopotamian "World System." American Anthropologist 94: 118-139.

Evans, A.

1921 The Palace of Minos. Macmillan, London.

Evans, J. D.

1964 Excavations in the Neolithic Settlement at Knossos. Annual of the British School at Athens 59: 132-240.

Frank, A. G.

1993 Bronze Age World System Cycles. Current Anthropology 34: 383-429.

Finley, M. I.

1973 The Ancient Economy. University of California Press, Berkeley.

1981 Early Greece. The Bronze and Archaic Ages. W. W. Norton, New York. 
[Page 25]

Journal of World-Systems Research

Gale, N. H., and Z. A. Stos-Gale

1982 Bronze Age Copper Sources in the Mediterranean: A New Approach. Science 216(4541): 11-19.

Gilman, A.

1981 The Development of Social Stratification in Bronze Age Europe. Current Anthropology 22: 1-23.

Haldane, C.

1993 Direct Evidence for Organic Cargoes in the Late Bronze Age. World Archaeology 24: $348-360$.

Hall, T. D.

1986 Incorporation in the World-System: Toward a Critique. American Sociological Review 51: 390-402.

Halstead, P.

1981 From Determinism to Uncertainty: Social Storage and the Rise of the Minoan Palace. In Economic Archaeology, edited by Alison Sheridan and Geoff Bailey, pp. 187213. British Archaeological Reports International Series 96, BAR, Oxford.

[Page 26]

Journal of World-Systems Research

Harris, $\mathrm{M}$.

1991 Cultural Anthropology. 3rd edition. Harper Collins, New York.

Huxley, G. L. 
1972Small Finds from Deposits. In Kythera. Excavations and Studies, edited by J.N. Coldstream and G.G. Huxley, pp. 205-219. Noyes Press, Park Ridge, N. J.

Jameson, M., Tj. H. van Andel, and C. Runnels

1994 A Greek Countryside. Stanford University Press, Stanford.

Jones, G., K. Wardle, P. Halstead, and D. Wardle

1986 Crop Storage at Assiros. Scientific American 254(3): 96-103.

Kardulias, P. N., and C. Runnels

1995 The Lithic Artifacts. In Artifact and Assemblage: Finds from A Greek Countryside, Volume I: The Prehistoric Pottery and the Lithic Artifacts, edited by C. Runnels, D.

Pullen, and S. Langdon, pp. 74-139. Stanford University Press.

Kemp, B. J., and R. S. Merrillees

1980 Minoan Pottery in Second Millennium Egypt. P. von Zabern, Mainz am Rhein.

[Page 27]

Joumal of World-Systems Research

Keswani, P. S.

1993 Models of Local Exchange in Late Bronze Age Cyprus. Bulletin of the American Schools of Oriental Research 292: 73-83.

Knapp, A. B.

1992 Bronze Age Mediterranean Island Cultures and the Ancient Near East, Part I. Biblical Archaeologist 52-72.

1993 Thalassocracies in Bronze Age Eastern Mediterranean Trade: Making an d Breaking a Myth. World Archaeology 24: 332-347.

Kohl, P. L.

1989 The Use and Abuse of World Systems Theory: The Case of the "Pristine" West Asian State. In Archaeological Thought in America, edited by C. C. Lamberg-Karlovsky, pp. 218-240. Cambridge University Press, New York. 
1992 The Transcaucasian "Periphery" in the Bronze Age. A Preliminary Formulation. In Resources, Power, and Interregional Interaction, edited by E. M. Schortman and P. A. Urban, pp. 117-137. Plenum Press, New York.

Leekley, D., and R. Noyes

1975 Archaeological Excavations in the Greek Islands. Noyes Press, Park Ridge, N.J.

McDonald, W. A., and R. H. simpson

[Page 28]

Journal of World-Systems Research

1969 Explorations in Southwest Peloponnese: 1964-1968. American Journal of Archaeology 73: 123-177.

McDonald, W. A. et al.

1975 Excavations at Nichoria in Messenia: 1972-1973. Hesperia 44: 69-141.

Muhly, J. D., F. Begemann, Ö. Öztunali, E. Pernicka, S. Schmitt-Strecker, and G. A. Wagner

1991 The Bronze Age Metallurgy of Anatolia and the Question of Local Tin Sources. In Archaeometry 90 , edited by E. Pernicka and G.A. Wagner, pp. 209-220. Birkhäuser, Verlag.

Mylonas, G. E.

1966 Mycenae and the Mycenaean Age. Princeton University Press, Princeton.

Özgüç, Tahsin

1963 An Assyrian Trading Outpost. Scientific American 208(2): 96-106.

Palaima, T. G.

1989 Cypro-Minoan Scripts: Problems of Historical Context. In Problems in Decipherment, edited by Y. Duhoux, T. G. Palaima, and J. Bennet, pp. 121-187. (BCILL 49).

[Page 29]

Journal of World-Systems Research 
Pirenne, $\mathrm{H}$.

1933 Economic and Social History of Medieval Europe. Harcourt, Brace \& World, New York.

Polanyi, K.

1957 The Economy as Instituted Process. In Trade and Market in the Early Empires: Economies in History and Theory, edited by K. Polanyi, C. Arensburg, and H. W. Pearson. Free Press, New York.

Pulak, C.

1988 The Bronze Age Shipwreck at Ulu Burun, Turkey: 1985 Campaign. American Journal of Archaeology 92: 1-37.

Pulak, C., F. Hentschel, C. Haldane

1992 Excavation of the Bronze Age shipwreck at Uluburun (Ka), Turkey. American Journal of Archaeology 96: 363 (abstract).

Renfrew, C.

1972 The Emergence of Civilisation. Methuen, London.

1982 Prehistoric Exchange. In An Island Polity, edited by C. Renfrew and M. Wagstaff, pp. 222-227. Cambridge University Press, Cambridge.

1984 Trade as Action at a Distance. Reprinted in Approaches to Social Archaeology, by Colin Renfrew, pp. 86-134. Edinburgh University Press, Edinburgh.

[Page 30]

Joumal of World-Systems Research

Renfrew, C., J. R. Cann, and J. E. Dixon

1965 Obsidian in the Aegean. Anmual of the British School at Athens 60: 225-247.

Renfrew, C., and J. F. Cherry (eds.) 
1986 Peer Polity Interaction and Socio-political Change. Cambridge University Press, New York.

Ridley, C., and K. A. Wardle

1979 Rescue Excavations at Servia 1971 -1973: A Preliminary Report. Anmual of the British School at Athens 74: 185-230.

Runnels, C. N.

1981 A Diachronic Study and Economic Analysis of Millstones from the Argolid, Greece. Unpublished $\mathrm{PhD}$ dissertation, Indiana University.

1983 Trade and Communication in Prehistoric Greece. Ekistics 302: 417-420.

1985a Trade and Demand for Millstones in Southern Greece in the Neolithic and the Early Bronze Age. In Prehistoric Production and Exchange: The Aegean and Eastern Mediterranean, edited by B. Knapp and T. Stech, pp. 30-43. UCLA Monographs in Archacology, Los Angeles.

1985b The Bronze-Age Flaked-Stone Industries from Lerna: A Preliminary Report. Hesperia 54: 357-391.

1988 Early Bronze-Age Stone Mortars from the Southern Argolid. Hesperia 57: 257-272.

[Page 31]

Journal of World-Systems Research

Rostovtzeff, M.

1941 The Social and Economic History of the Hellenistic World. 2 vol. Clarendon Press, Oxford.

Schortman, E. M., and P. A. Urban

1987 Modeling Interregional Interaction in Prehistory. In Advances in Archaeological Method and Theory, vol. 11, edited by M. B. Schiffer, pp. 37-95. Academic Press, New York.

1992 Current Trends in Interaction Research. In Resources, Power, And Interregional Interaction, edited by E. M. Schortman and P. A. Urban, pp. 235-255. Plenum Press, New York. 
Shelford, P., F. Hodson, M. E. Cosgrove, S. E. Warren, and C. Renfrew

1982 The Sources and Characteristics of Melian Obsidian. In An Island Polity, edited by

C. Renfrew and M. Wagstaff, pp. 182-192. Cambridge University Press, Cambridge.

Sherratt, A.

1993 What Would a Bronze-Age World System Look Like? Relations between

Temperate Europe and the Mediterranean in Later Prehistory. Journal of European Archaeology 1(2): 1-57.

Sherratt, S., and A. Sherratt

1993 The Growth of the Mediterranean Economy in the Early First Millennium BC.

World Archaeology 24: 361-378.

[Page 32]

Journal of World-Systems Research

Tartaron, T., and C. Runnels

1992 Palaeolithic Research at Kokkinopilos in Epirus. Old World Archaeology

Newsletter 15(3): 26-30.

Theocharis, D.

1981 Neolithikos Politismos. Morfotiko Idrima Ethnikis Trapezis, Athinai.

Torrence, R.

1986 Production and Exchange of Stone Tools. Cambridge University Press, Cambridge.

van Andel, Tj. H. and C. Runnels

1988 An Essay on the 'Emergence of Civilization' in the Aegean World. Antiquity 62:

234-247.

Van Horn, D.

1980 Observations Relating to Bronze Age Blade Core Production in the Argolid of

Greece. Journal of Field Archaeology 7: 487-492.

Vermeule, E. 
[Page 33]

Journal of World-Systems Research

1964 Greece in the Bronze Age. University of Chicago Press, Chicago.

Wace, A. J. B.

1949 Mycenae, an Archaeological History and Guide. Princeton University Press, Princeton.

Wace, A. J. B., and M. S. Thompson

1912 Prehistoric Thessaly. Cambridge University Press, Cambridge.

Wallerstein, I.

1974 The Modern World-System I: Capitalist Agriculture and the Origins of the European World-Economy in the Sixteenth Century. Academic Press, New York.

Warren, $P$.

1972 Myrtos, an Early Minoan Settlement in Crete. British School at Athens Supplementary Volume No. 7. London.

Warren, P., and J. Tzedhakis

1974 Debla, an Early Minoan Settlement in Western Crete. Annual of the British School at Athens 69: 299-342.

[Page 34]

Journal of World-Systems Research

Watson, A.

1983 Chipped-Stone Artifacts from Servia in Greek Macedonia. Journal of Field Archaeology 10: 120-123.

Weber, $\mathrm{M}$. 
1976 The Agrarian Sociology of Ancient Civilizations. Transl. by R. I. Frank. Humanities Press, Atlantic Highlands. Originally published 1909.

Weiner, $\mathrm{M}$.

1984 Crete and the Cyclades in LM I: The Tale of the Conical Cups. In The Minoan Thalassocracy. Myth and Reality, edited by Robin Hägg and Nanno Marinatos, pp. 17 26. Skrifter Utgivna Av Svenska Institutet I Athen, 4, XXXII, Stockholm.

1987 Trade and Rule in Palatial Crete. In The Function of the Minoan Palaces, edited by Robin Hägg and Nanno Marinatos, pp. 261 -268. Skrifter Utgivna Av Svenska Institutet I Athen, 4, XXXV, Stockholm.

1990 Round-Table Comments. In Aegean Seals, Sealings and Administration, edited by Thomas G. Palaima, pp. 236-239. Aegaeum 5, Annales d' Archeologie Egeenne de I'Universite de Liege, University de Liege, Liege, Belgium.

1991a The Isles of Crete? The Minoan Thalassocracy Revisited. In Thera and the Aegean World III, Volume 1, edited by D. A. Hardy, C. G. Doumas, J. A. Sakellarakis, and P. M. Warren. The Thera Foundation, London.

$1991 \mathrm{~b}$ The Nature and Control of Minoan Foreign Trade. In Bronze Age Trade in the Mediterranean, edited by N. H. Gale, pp. 325-350. Studies in Mediterranean Archaeology No. 90. Paul Astroms Forlag, Goteborg.

Yener, K. A., E. V. Sayre, E. C. Joel, H. Özbal, I. L. Barnes, and R. H. Brill

[Page 35]

Journal of World-Systems Research

1991 Stable Lead Isotope Studies of Central Taurus Ore sources and Related Artifacts from Eastern Mediterranean Chalcolithic and Bronze Age Sites. Journal of Archaeological Science 18:541-577.

Zagarell, A.

1989 Pastoralism and the Early State in Greater Mesopotamia. In Archaeological Thought in America, edited by C.C. Lamberg-Karlovsky, pp. 280-301. Cambridge University Press, New York.

[Page 36]

Journal of World-Systems Research 